основи фінансової стійкості банків. Актуальні проблеми розвитку економіки регіону. 2019. Вип. 15. Т.1. С. 95-105.

10. Claessens S., Horen N. Foreign banks: trends, impact and financial stability. IMF Working Paper WP/12/10 (January 2012). URL: https://www.imf.org/external/pubs/ ft/wp/2012/wp1210.pdf. (дата звернення: 10.11.2020р.)

11. Bankers without Borders. Global Financial Development Report 2017/2018. URL: https://openknowledge.worldbank.org/bitstream/handle/10986/28482/9781464811487.pdf. _ (дата звернення: 10.11 .2020 р.)

12. Дятлова Ю. В. Концепція конкурентної інтерналізації в банківському секторі: еволюція теорій $\mathrm{i}$ наукові положення. Проблеми і перспективи економіки та управління. 2019. № 1 (17). С. 219227.

\title{
References
}

1. Diatlova, Yu. V. "Internationalization, integration and internalization in the banking sector: theoretical and methodological aspects in the context of global competition.”State and regions. Economics and $\begin{array}{lllll}\text { Entrepreneurship } & \text { Series, } & 6 & \text { no. }\end{array}$ pp. 145-151.

2. Clarke, G., Cull, R., Soledad, M., Peria, M., and S. Sánchez "Foreign Bank Entry: Experience, Implications for Developing Countries, and Agenda for Further Research.” World Bank Research Observer, vol. 18, 2003, pp. 25-40.

3. Claessens, S. "Competitive Implications of Cross-Border Banking”. CrossBorder Banking: Regulatory Challenges. New Jersey, World Scientific Publishing, 2006, pp. 151-182.

4. Chava, S., and A. Purnanandam. "The Effect of Banking Crisis on Bank-Dependent Borrowers.”.Journal of Financial Economics, vol. 99, 2011, pp. 116-135.

5. Levitt, T. "The Globalization of Markets.” Harvard Business Review, 61 (May/June), 1983, pp. 92102.

6. Geets, V. "Foreign capital in the banking system of Ukraine." Mirror of the week, no. 26 (605), July 8-14, 2006, www.dt.ua/2000/2040/53895. Accessed 10 Nov. 2020.

7. Dzyublyuk, O V., editor. Banking system of Ukraine: formation and development in the context of globalization of economic processes. Ternopil, "Vector”, 2012.

8. Karcheva, G T., editor. Efficiency and competitiveness of the banking system of Ukraine. Kyiv: SHEI "University of Banking”, 2016. 279 p.

9. Pylypiv N. I., Piatnychuk I. D., and I. I.Boryshkevych "Conceptual aspects of business intelligence as a basis for financial stability of banks”. Current problems of economic development of the region, Is. 15, vol. 1, 2019, pp. 95-105.

10. Claessens S., and N.Horen. "Foreign banks: trends, impact and financial stability". IMF Working Paper WP/12/10 (January 2012), www.imf.org/external/pubs/ft/wp/2012/ wp1210.pdf. Accessed 10 Nov. 2020.

11. Bankers without Borders. "Global Financial Development Report 2017/2018”, openknowledge.worldbank.org/bitstream/handle/10986/28482/9781464811487.pdf. Accessed 10 Nov. 2020.

12. Diatlova, Yu. V. "The concept of competitive internalization in the banking sector: the evolution of theories and scientific positions." Problems and prospects of economics and management, no. 1 (17), 2019, pp. 219-227.

УДК 336.77

doi: 10.15330/apred.1.16.74-83

\section{ДОЦІЛЬНСТЬ РОЗВИТКУ НАЦІОНАЛЬНОГО РИНКУ КРЕДИТНИХ ДЕРИВАТИВІВ}

${ }^{1}$ Підприємець

тел.: 050-888-48-85

e-mail: mkoshevtsova@gmail.com

${ }^{2}$ Прикарпатський національний університет 
імені Василя Стефаника,

Міністерство освіти і науки України, кафедра міжнародних економічних відносин, вул. Чорновола, 1, м. Івано-Франківськ, 76000 , Україна, тел.: 099-282-11-22, e-mail: Rodinaoksana78@gmail.com

Анотація. Статтю присвячено дослідженню сутності ринку кредитних деривативів, його перевагам та недолікам, розгляду доцільності розвитку національного ринку кредитних деривативів. Визначено категорії та інструменти ринку деривативів.

Через молодість ринку кредитних деривативів його доля в загальному об'ємі операцій 3 деривативами доки мала, але має великі перспективи. Сфера їхнього застосування не обмежується банківською діяльністю або одним ринком. Виділення ризику в самостійний об'єкт торгівлі призвело до виникнення нових форм застосування кредитних деривативів, де вони можуть виступати альтернативою традиційним інструментам страхування, а також мають досить оригінальний підхід до управління відомим ризиком. У випадку кредитування вони $€$ просто незамінними, оскільки є засобом страхування від несприятливої дії кредитного ризику.

Розглянуто функції кредитних деривативів на сучасному етапі. Визначено стратегічні напрями розвитку вітчизняного ринку деривативів. 3'ясовано, що кредитні деривативи створюють умови для накопичення системних ризиків, тобто збільшують імовірність настання системних подій несприятливого характеру, викликаних екзогенними чи ендогенними причинами, які спричиняють нестабільність фінансового ринку. Саме ці фактори необхідно враховувати, прагнучи впровадити використання кредитних деривативів в українському банківському секторі.

Проаналізовано світовий досвід організації системи регулювання ринку кредитних деривативів як способу мінімізації негативних наслідків. 3 огляду на світовий досвід, можна сказати, що з боку держави приділяється багато уваги розвитку сегменту фінансового ринку, як ринок кредитних деривативів, чого не вистачає українському банківському сектору.

Використовуючи світовий досвід, переваги та можливі негативні наслідки ринку кредитних деривативів, для розвитку кредитування в Україні необхідним є ринок кредитних деривативів.

Ключові слова: ринок кредитних деривативів, похідні фінансові інструменти, ризик, кредитний ризик, банківська сфера.

\title{
Koshevtsova M. A', Rodina O. G. ${ }^{2}$ SUITABILITY OF DEVELOPMENT OF THE NATIONAL MARKET OF CREDIT DERIVATIVES
}

\author{
1 Entrepreneur, \\ tel.: 050-888-48-85, \\ e-mail: mkoshevtsova@gmail.com \\ ${ }^{2}$ Vasyl Stefanyk Precarpathian National University, \\ Ministry of Education and Science of Ukraine, \\ Department of International Economic Relations, \\ Chornovola str., 1, Ivano-Frankivsk, \\ 76000, Ukraine, \\ tel.; 099-282-11-22, \\ e-mail: Rodinaoksana78@gmail.com
}

\begin{abstract}
The article is devoted to studying of the essence of the credit derivatives market, its advantages and disadvantages, consideration of the suitability of development of the national market of credit derivatives. Categories and instruments of the derivatives market are defined.

Due to the youth of the credit derivatives market, its share in the total volume of derivative
\end{abstract}


transactions is still small, but has great prospects. Their scope is not limited to banking or a single market. The allocation of risk to a separate object of trade has led to the emergence of new forms of credit derivatives, where they can be an alternative to traditional insurance instruments, as well as have very individual approach to managing established risk. In the case of lending, they are simply irreplaceable, as they are a way of insuring for adverse credit risk.

The functions of credit derivatives at the present stage are considered. Strategic directions of development of the domestic derivatives market are determined. It has been found that credit derivatives create the conditions for the accumulation of systemic risks, so increase the degree of probability of the adverse systemic successor caused by exogenous or endogenous reason that lead to financial market instability. These factors must be taken into account press for introduce the use of credit derivatives in the Ukrainian banking sector.

The world experience of organization of credit derivatives market regulation system as a way to minimize negative consequences is analyzed. Given the world experience, we can say that the state pays much attention to the development of the financial market segment, as a market of credit derivatives, which is lacking in the Ukrainian banking sector.

Using the world experience, advantages and possible negative consequences of the credit derivatives market, the credit derivatives market is necessary for the development of lending in Ukraine.

Keywords: credit derivatives market, derivative financial instruments, risk, credit risk, banking.

Вступ. Ринок кредитних деривативів (далі за текстом - РКД), як інструмент управління кредитним ризиком, в світовій практиці дуже поширене явище. РКД привертає увагу багатьох теоретиків та практиків. Його категорійність, принципи, досвід використання вивчали Примостка Л.О., Кузнецова Л.В., Мінохіна І. М., Колодізєв О. М., Коцюба О. В., Гордон В.Б. Були спроби впровадження в національну практику. Проте, досі РКД не набув поширення в Україні, адже залишаються недостатньо висвітленими питання організації системи регулювання РКД.

Постановка завдання. Мета дослідження - розглянути доцільність розвитку національного ринку кредитних дериватив, розкрити сутність та функції РКД, узагальнити його переваги та недоліки, проаналізувати світовий досвід організації системи регулювання РКД.

Результати. Ринок кредитних деривативів - це система ринкових відносин, що забезпечують перерозподіл фінансових потоків шляхом купівлі-продажу кредитних ризиків або захисту від кредитних ризиків [1]. Його учасники отримали можливість перерозподіляти кредитні ризики, не оформлюючи перехід прав власності на базові активи. 3 організаційної точки зору РКД являє собою світові фінансові центри (Лондон, Франкфурт, Нью-Йорк, Токіо), де проходять операції купівлі-продажу захисту від кредитного ризику. Перша угода з кредитними деривативами була укладена 1992 року американським банком "Banker Trust" зі свопами на дефолт [2].

Найбільшими центрами у світі за обсягами угод із кредитними деривативами $€$ США, Великобританія, Німеччина. Саме в цих країнах вже сформувався ринок кредитних деривативів, який $\epsilon$ запорукою ліквідності банківських позик. Рекордсменами з випуску дефолтних свопів стали страховик AIG та інвестбанк Lehman Brothers (на двох - більше \$1,1 трлн). В останні роки активно формується біржовий ринок індексних інструментів, що страхує кредитний ризик. Він концентрується в Чикаго [3, с. 326].

У результаті використання кредитних деривативів можна досягти значного рівня диверсифікованості ризиків по різних ринках, галузях, географічних регіонах. Результатом такого підходу буде низький рівень концентрації виданих позичок і схильності до кредитного ризику однорідних контрагентів. Істотною перевагою кредитних деривативів $\epsilon$ їхня здатність передавати кредитний ризик певного активу без 
передачі прав власності на цей самий актив.

Класифікація кредитних деривативів представлена на рис.1.

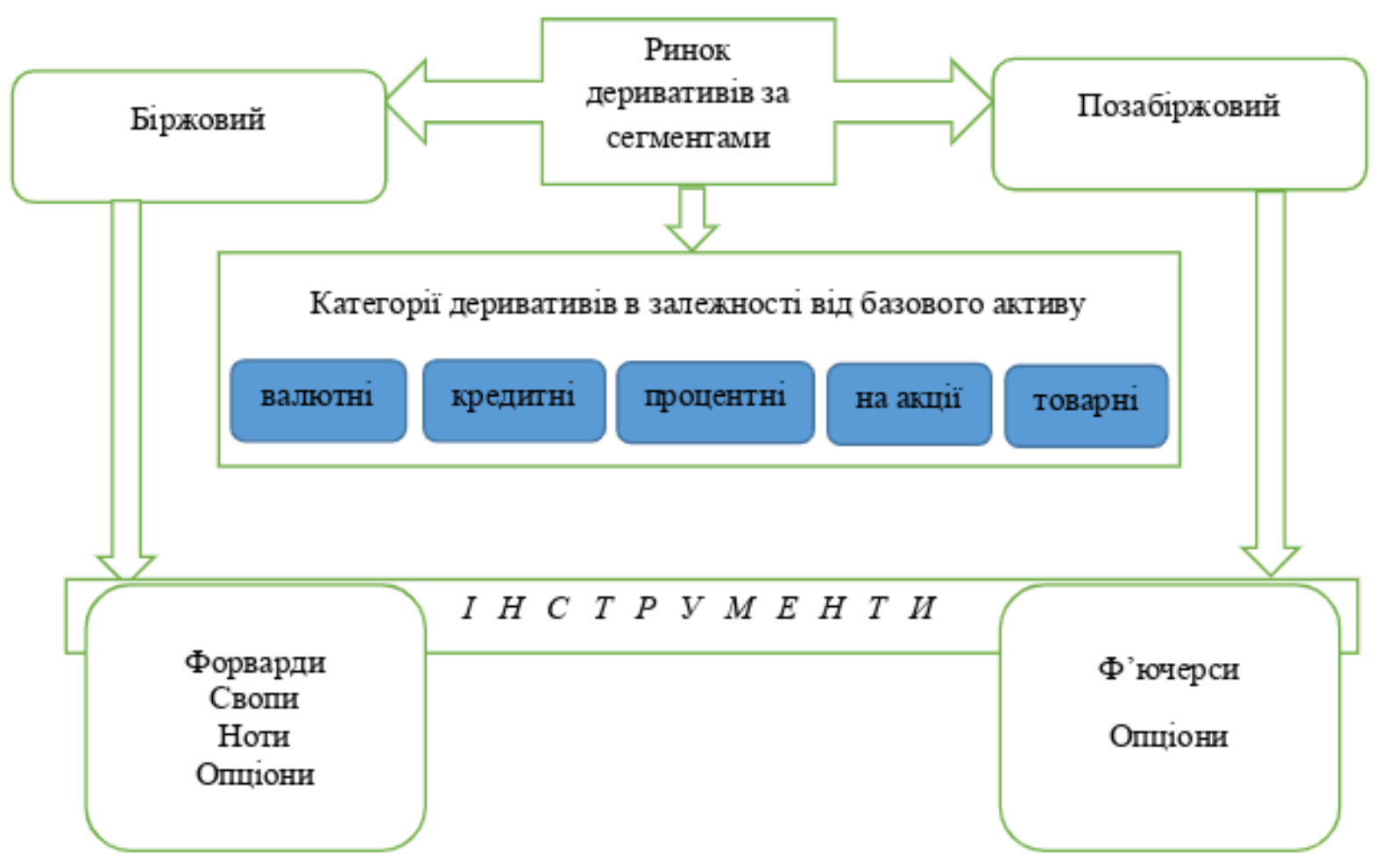

Puc.1. Категорії та інструменти ринку деривативів*

* Складено авторами з використанням $[1,4,5]$

Fig.1. Derivatives market categories and instruments*

Основними інструментами в структурі ринку кредитних деривативів є кредитні дефолтні свопи, свопи на сукупний доход, деривативи на кредитний спред, зв'язані кредитні ноти, перепаковані ноти та гібридні інструменти. Через молодість ринку кредитних деривативів його доля в загальному об'ємі операцій 3 деривативами доки мала, але має великі перспективи.

Сфера їхнього застосування не обмежується банківською діяльністю або одним ринком. Виділення ризику в самостійний об'єкт торгівлі призвело до виникнення нових форм застосування кредитних деривативів, де вони можуть виступати альтернативою традиційним інструментам страхування, а також мають досить оригінальний підхід до управління відомим ризиком.

У випадку кредитування вони є просто незамінними, оскільки задумані як засіб страхування від несприятливої дії кредитного ризику, сьогодні $\epsilon$ досить багатофункціональними (рис. 2). 


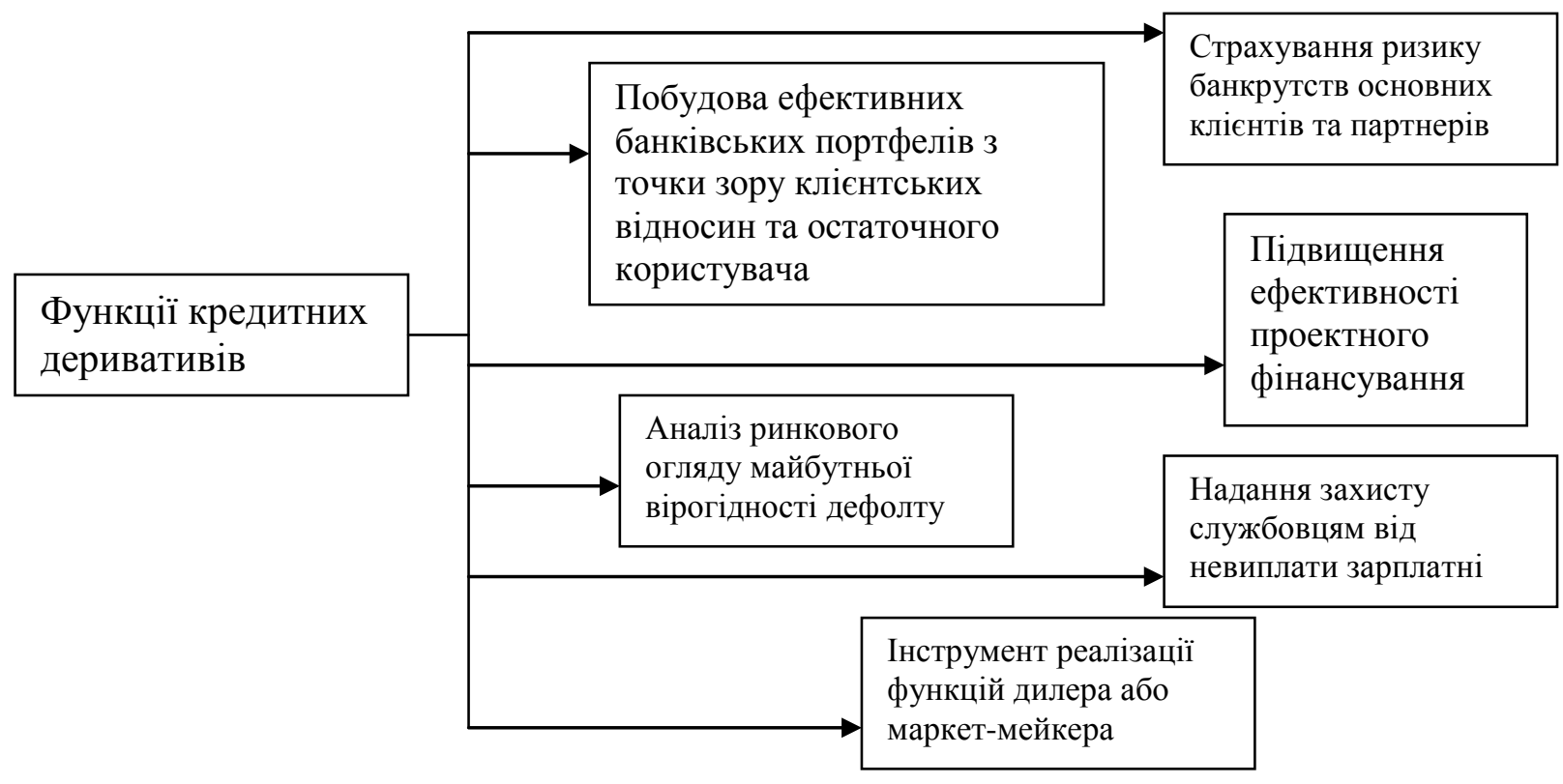

Puc. 2. Функції кредитних деривативів на сучасному етапі*

* Складено авторами з використанням [1-6]

Fig. 2. Functions of credit derivatives at the present stage*

Отже, кредитні деривативи - це вид структурованих фінансових інструментів, які відокремлюють кредитний ризик від активу та дозволяють бенефіціару перенести кредитний ризик, пов'язаний $з$ цим активом, на гаранта [5, с.169].

Під час виконання ними функцій, пов'язаних із банківськими операціями, основною перевагою використання цих інструментів є можливість створення більш ефективних диверсифікованих банківських портфелів та скорочення трансакційних витрат.

Також кредитні деривативи $є$ найдешевшим способом мінімізації ризику по окремих кредитах та дають змогу банкам із вузькоспеціалізованою сферою кредитування зменшувати вплив ризику концентрації, який пов'язаний із наданням значних позичок одному позичальнику або групі пов'язаних позичальників. Досягається це шляхом придбання захисту від дефолту конкретного позичальника та через додаткове хеджування ризику погіршення кредитних характеристик активів. Якщо основна мета банку полягає у зниженні ризику концентрації, то найбільш правильним рішенням буде купівля кредитних деривативів. У разі, якщо необхідною $\epsilon$ диверсифікація кредитного портфеля, тоді банк має продавати їх. Після продажу кредитного ризику банки можуть привести свій кредитний портфель відповідно до внутрішніх нормативів і здійснювати ефективну кредитну політику. У результаті використання кредитних деривативів банки мають можливість вивільняти свій баланс від проблемних позичок шляхом їх виведення на спеціальні забалансові рахунки [5, с. 169].

Таким чином, кредитні деривативи мають безліч переваг, особливо для банківського ринку. Проте, слід звернути увагу на основний недолік обігу кредитних похідних фінансових інструментів: їх незабезпеченість матеріальними активами, наслідком чого $є$ надмірне «роздування» фінансових активів, що сприяє формуванню «фінансових бульбашок», які, своєю чергою, можуть призвести до краху цілої економічної системи.

Так, саме кредитні деривативи стали однією з причин світової фінансової кризи 2008 р. через надмірну концентрацію великої кількості фінансових ресурсів, не 
підтверджених реальними активами. Доки ця так звана «фінансова бульбашка» росла повільніше, ніж економіка, інвестори через купівлю-продаж активів за ціною, вищою за їх внутрішню, реальну вартість, отримували надзвичайні прибутки. Але потім «бульбашка», навпаки, почала рости швидше, ніж економіка, i, досягнувши свого максимального розміру, лопнула. Прогноз Британської банківської асоціації передбачав, що в 2008 р. ринок мав сягнути 33 трлн. дол. США. Насправді ж його розмір становив майже вдвічі більше - 60 трлн дол. Через захоплення свопами AIG у вересні 2008 р. опинилися на межі банкрутства, а банк Lehman Brothers збанкрутував [5, c.169].

Неконтрольоване зростання РКД призвело до величезних втрат великих компаній. Так, у 2008 році 6,4 млрд дол. США втрат зафіксував французький банк Société Générale від несанкціонованої торгівлі ф'ючерсом на індекси акцій. Торговельна компанія Sumitomo Corporation в 1995-1996 рр. втратила 3,46 млрд дол. США від несанкціонованих операцій протягом 10-тирічного терміну керівника торговельного відділу. У 2010 р. британський підрозділ швейцарського банку UBS зазнав втрат у 1,83 млрд. дол. США від несанкціонованих операцій працівником з цінними паперами біржового фонду (ETF). У 2005 р. був зафіксований випадок з несанкціонованими операціями на ф'ючерсному ринку міді одним з працівником торговельного відділу китайського державного резерву. Як бачимо 3 наведених прикладів, випадки несанкціонованих операції не мають чіткої концентрації, а траплялися в різних структурах за типом діяльності, в різні роки, в різних країнах та проводилися через різні інструменти. Показовим прикладом свідомого збільшення ризиків є втрата 6,7 млрд. дол. США фінансовою установою JP Mogan Chase у 2012 p. [7]

Все ускладнюється тим, що в продавців досить часто не було адекватних резервів, щоб компенсувати втрати інвесторів. Таким чином, ринок кредитних деривативів $\epsilon$ дуже непрозорим, позабіржовим, оцінювати його реальні обороти немає ніякої можливості, а учасники цього ринку не прагнуть переходити на біржові розрахунки 3 використанням технології центрального контрагента. Проте варто зазначити, що загрозливим $\epsilon$ не питання значного росту об'єму кредитних деривативів, а необгрунтованість його реальними потребами економіки. Адже коли ці інструменти використовуються за своєю першочерговою місією (страхування повернення кредитів та зменшення ризикованості кредитного портфелю), то дозволяють урівноважити попит та пропозицію, знаходячись на боці “вільного ринку” [3, с. 326].

Отже, кредитні деривативи створюють умови для накопичення системних ризиків, тобто збільшують імовірність настання системних подій несприятливого характеру, викликаних екзогенними чи ендогенними причинами, які спричиняють нестабільність фінансового ринку. Саме ці фактори необхідно враховувати, прагнучи впровадити використання кредитних деривативів в українському банківському секторі.

Багато вітчизняних учених-економістів і практиків вважають, що відсутність розвинутого ринку деривативів в Україні зумовлена саме недосконалістю, а точніше відсутністю спеціального нормативно-правового підгрунтя. У чинному вітчизняному податковому законодавстві зазначено важливі ази функціонування ринку деривативів, проте відсутність спеціального закону стримує потенційний розвиток основних учасників ринку похідних - банків і міжнародних інвесторів.

Відсутність грунтовної законодавчої бази не є єдиною та основною проблемою ринку деривативів в Україні. Проте має місце замкнуте коло: з одного боку - низька активність на ринку, зумовлена відсутністю інфраструктури, а з іншого - необхідність інвестування коштів у побудову інфраструктури $\epsilon$ необгрунтованою через низький попит на похідні інструменти [8, с. 246-247]. 
Стратегічними напрямами розвитку вітчизняного ринку деривативів є: розширення інструментарію строкового ринку; автоматизація та модернізація торгової інфраструктури, розвиток електронної торгівлі; вирішення питань правового регулювання функціонування біржового ринку; розширення кола учасників шляхом забезпечення ефективного механізму залучення до біржових торгів індивідуальних інвесторів [9, с.62].

Роль каталізатора процесів популяризації й упровадження фінансових деривативів у повсякденну діяльність суб'єктів ринкових відносин мають відігравати комерційні банки. Зазначимо, що для останніх діяльність, пов'язана 3 такими деривативами, створює низку привабливих можливостей: окрім механізмів хеджування строковий ринок дає змогу істотно розширити спектр банківських продуктів і послуг. Цими можливостями банки можуть скористатись як для проведення власних операцій, так i для виконання посередницьких функцій між клієнтами й ринком, що сприятиме підвищенню банківських доходів. [9, с. 65].

Але зважаючи на нестабільність економічної системи в Україні, нормативноправове підгрунтя не зможе врятувати від системних ризиків, які можуть стати наслідками безпечного використання РКД. Спираючись на світовий досвід, необхідно побудувати систему регулювання ринку кредитних деривативів.

Регулювання ринку деривативів має на меті підвищення ефективності ринку та зниження систематичного ризику. Системи регулювання ринків деривативів у розвинутих країнах впливають як на особливості їх організації, так і на локалізацію.

В США існують три основні фінансові регулятори, повноваження яких безпосередньо відносяться до діяльності на ринку деривативів: Комісія 3 торгівлі товарними ф'ючерсами, Комісія з цінних паперів та бірж та регулівні органи банківської сфери. Нагляд за діяльністю банків з деривативами в США здійснюється Офісом валютного контролю Федеральної корпорації страхування депозитів Федеральної резервної системи, або банківськими регуляторами штатів, в залежності від типу банківських статутів, страхування депозитів та членства у Федеральній резервній системі (рис. 3).

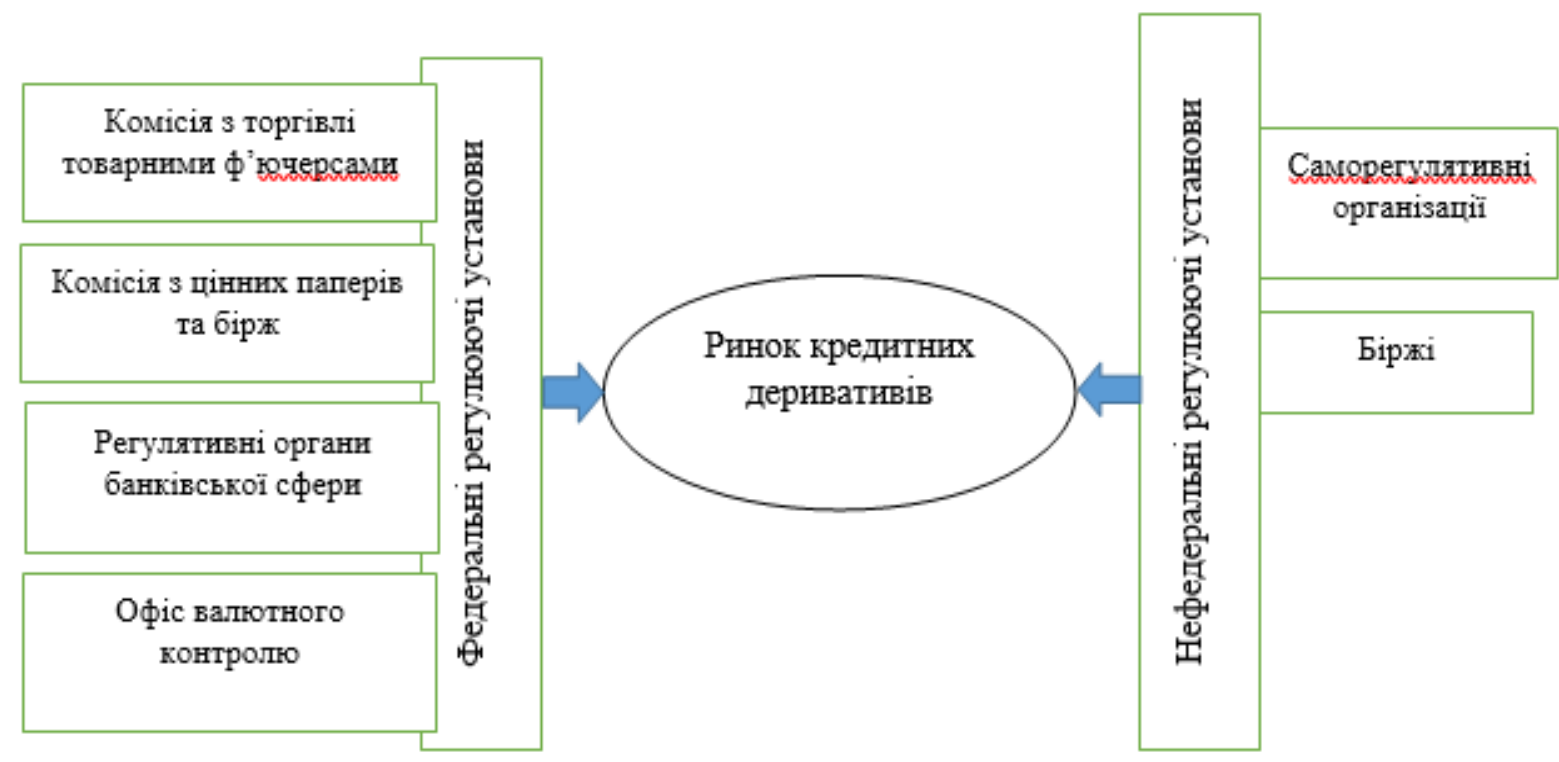

Рис. 3. Система регулювання РКД в США

*Складено авторами з використанням [10]

Fig. 3. The system of regulation of the credit derivatives market in the USA 
Окрім федеральних регулюючих установ невід'ємною складовою в системі регулювання ринку деривативів США $\epsilon$ біржі та саморегулівні організації, які відіграють важливу роль в процесі визначення функціональних вимог до інструментів, учасників ринку та взаємовідносин між ними.

Законодавство США в сфері регулювання деривативів постійно трансформується. Як видно 3 огляду вище, навіть величезні американські компанії періодично мають втрати через «неякісні» операції на РКД.

Розвиток позабіржового ринку деривативів у цій країні зумовив необхідність реформування існуючої неефективної системи регулювання фінансового сектору та впровадження гнучкої моделі законодавчого регулювання. 3'явилась відносно нова тенденція у регулюванні ринків деривативів США, зміст якої полягає у прагненні позабіржового ринку до набуття рис стандартизованості та запровадження механізмів, що притаманні біржовому ринку. До таких механізмів необхідно віднести інститут клірингової палати, який вважається класичним біржовим механізмом. Також важливою тенденцією є процес перегляду традиційних принципів побудови системи позабіржового ринку, як ринкового середовища, що складається з великих потужних інституційних операторів. Спостерігається тенденція до утворення в межах позабіржового ринку роздрібного ринку для дрібних інвесторів, що дозволить не тільки збільшити інвестиційну привабливість фінансових ринків США, а й значно підвищити рівень їх ліквідності. У цілому регулювання деривативів в США в окремих випадках $\epsilon$ повним (біржові деривативи та окремі позабіржові), а іноді регулювання майже повністю відсутне [10, с.11].

На відміну від США, однією з основних особливостей регулювання ринку деривативів у Великій Британії $є$ наявність єдиного фінансового регулятора Управління фінансових послуг, яке було створено в 1999р. відповідно до нового Закону про фінансові послуги та ринки. Друга особливість - це різні підходи до регулювання професійних та непрофесійних учасників відповідно досвіду та ступеня участі у ринкових операціях, а також їхньої відносної потреби у захисті [10, с.12].

Регулювання та нагляд на позабіржових ринках деривативів в інших країнах, як правило, передбачає визначення трансакції, яку дозволяється проводити, отримання дозволів та ліцензій контрагентами, обмеження на участь в операціях, правила торгівлі та формування цін на ринку, вимоги щодо розкриття інформації. У більшості країн не встановлено обмежень на створення позабіржових деривативів i, таким чином, не обмежується коло продуктів, з якими може здійснюватися торгівля. В більшості країн правила допуску до участі у позабіржовому ринку деривативів, як правило, залежать від того, яку діяльність здійснюють інститути - виключно за свій власний рахунок, або проводять трансакції від імені своїх клієнтів. Більшість країн не встановлює спеціальних ліцензійних вимог для партнерів на позабіржовому ринку. Деякі європейські країни, наприклад Іспанія та Франція, обмежують використання позабіржових деривативів інститутами спільного інвестування. Німеччина, на додаток до цього, обмежує використання позабіржових деривативів страховими компаніями та іпотечними банками. Більшість країн не встановлюють явних правил, спрямованих проти виконання угод 3 використанням багатосторонніх електронних засобів, a, наприклад, у Великій Британії, Нідерландах та Швеції прямо дозволяють централізований кліринг з позабіржових деривативів [10, с. 12].

3 огляду на світовий досвід, можна сказати, що з боку держави приділяється багато уваги розвитку сегменту фінансового ринку, як РКД, чого не вистачає українському банківському сектору.

Висновки. Таким чином, можна зробити висновки, що крім традиційних способів зниження кредитного ризику доцільним $\epsilon$ впровадження в українську 
банківську систему ринку кредитних деривативів. РКД - система ринкових відносин, «крок вперед» для банківської системи України, необхідність для іiі розвитку та розвитку кредитування. Поки банки включатимуть в плату за користування ресурсами ризик, відсоткові ставки за кредитними операціями залишатимуться непомірно високими для бізнесу, що гальмує розвиток бізнесу в країні, а отже, й всієї економіки. Але маючи негативні побічні явища та схильність до системного ризику, використання його має бути регульованим на рівні держави, НБУ та установ. За роки становлення біржового ринку було зроблено кілька спроб започаткування РКД, але операції на ньому не набули поширення через низку факторів, в тому числі відсутності правового та інформаційного поля. Використовуючи світовий досвід, переваги та можливі негативні наслідки РКД, для розвитку кредитування в Україні необхідним є ринок кредитних деривативів.

1. Миськів Г. В. Кредитні деривативи як новітні інструменти кредитного ринку. Ефективна економіка. 2014. № 7. ULR: http://nbuv.gov.ua/UJRN/efek_2014_7_10 (дата звернення: 10.11.2020 p.)

2. Кузнецова Л.В. Інноваційні фінансові інструменти захисту банків від ризиків на кредитному ринку. ULR : https://core.ac.uk/download/pdf/147039873.pdf(дата звернення: 10.11.2020 p.)

3. Мінохіна І.М. Кредитні деривативи як інструмент ризик менеджменту та індикатора кризових явищ. Наукові записки. Серія "Економіка". Випуск 14. С. 324-329.

4. Банківська система України: інституційні зміни та інновації: кол. моногр. / [Л.О. Примостка, М.І. Диба, І.В.Краснова та ін.]; за ред.Л.О. Примостки. К.: КНЕУ, 2015. 434c.

5. Кузнецова Л.В., Абрамова Т.Ю. Особливості використання кредитних деривативів в діяльності банків. Науковий вісник Херсонського державного університету. 2016. Випуск 18.ч.1. С. 168-171.

6. Фурман В. М. Комплексне банківське страхування. Фінанси, облік і аудит. 2013. Вип. 1. С. 188-200. ULR: http://nbuv.gov.ua/UJRN/Foa_2013_1_25. (дата звернення: 10.11.2020р.)

7. Кучер Т.Л., Радзієвська В.М. Аналіз негативних наслідків використання інноваційних фінансових інструментів на світовому фінансовому ринку. Фінанси, облік $і$ аудит. 2015. № 25(1). C. $126-146$.

8. Колодізєв О. М., Коцюба О. В. Аналіз перспектив розвитку ринку деривативів в Україні з урахуванням вирішення проблеми його нормативно-правового регулювання. Проблеми економіки. 2016. № 1. С. 242-248. ULR: http://nbuv.gov.ua/UJRN/Pekon_2016_1_31 (дата звернення: 10.11 .2020 р.)

9. Примостка Л. О., Краснова І. В. Біржовий ринок деривативів в Україні: історія, сучасність, перспективи розвитку. Фінанси України. 2014. № 7. С. 49-65.

10. Гордон В.Б. Ринок похідних фінансових інструментів та перспективи його розвитку в Україні: автореферат дисертації на здобуття наукового ступеня кандидата економічних наук: спеціальність 08.04.01 «Фінанси, грошовий обіг і кредит». К., 2005. 20 с.

\section{References}

1. Myskiv, G. "Credit derivatives as a modern instruments of credit market." Effective economy, no. 7, 2014. The Vernadsky National Library of Ukraine, nbuv.gov.ua/UJRN/efek_2014_7_10. Accessed 10 Nov. 2020.

2. Kuznetsova, L.V. "Innovative financial instruments to protect the bank from risks in the credit market.” Core, core.ac.uk/download/pdf/147039873.pdf. Accessed 10 Nov. 2020.

3. Minokhina, I. M.” Credit derivatives as a risk management tool and an indicator of crisis phenomena." Scientific notes. Economics series, issue 14, pp. 324-329.

4. Banking system of Ukraine: institutional changes and innovations: coll. monograph, ed. L.O. Primostka. Kyiv, KNEU, 2015.

5. Kuznetsova, L.V., and T.Y. Abramova. "Features the use of credit derivatives in the activities of banks.” Scientific Bulletin of Kherson State University, Issue 18, p.1, 2016, pp. 168-171.

6. Furman, V.M. "Complex banking insurance.” Finance, accounting and auditing, no. 1, 2013, pp. 188200. The Vernadsky National Library of Ukraine, nbuv.gov.ua/UJRN/Foa_2013_1_25. Accessed 10 Nov. 2020.

7. Kucher, T. L., and V.M. Radzievska. "Analysis of the negative consequences of the use of innovative financial instruments in the global financial market.” Finance, Accounting and Auditing, no. 5, 2015, pp. 126-146. 
8. Kolodizev, O.M., and O. V. Kotsiuba. "The Analysis of Prospects for Derivatives Market Development in Ukraine in View of Solving the Problems of its Normative Legal Regulation.” Problems of the economy, no. 1, 2016, pp. 242-248. The Vernadsky National Library of Ukraine, nbuv.gov.ua/UJRN/Pekon_2016_1_31. Accessed 10 Nov. 2020.

9. Prymostka, L., and I. Krasnova. "Derivatives exchange market in Ukraine: the history, the present, and future development.” Ukraininan finances, no. 7, 2014, pp. 49-65.

10. Hordon, V.B. Financial derivatives market and prospects of its development in Ukraine. Thesis abstract of Cand. Sc. (Econ.). Kyiv, National Economic University, Kyiv, 2005. 